\title{
Tanulmány
}

\author{
Dobi Edit
}

\section{A szemiotikai textológiai jelentésreprezentáció hozadéka József Attila Mama címü versének elemzésében}

\begin{abstract}
The output of the representation of semiotic textological meaning in the analysis of Attila József's poem Mama [Mother]

In the framework of my study, I illustrate via the analysis of Attila József's poem Mama with what information the complex signal model interpreted in the context of semiotic textology and the system of meaning planes contribute to the representation of the meaning of the text. The theoretical framework of meaning analysis is comprised by semiotic textology. In the representation of the meaning, the interpreter of the text (and, obviously, its creator) is present as a unique mental content or as a unique mental function. In the context of this conception, the basis of textuality is the intuition of the recipient of the text concerning whether or not it functions as a text for a currently perceived complex sign.

Keywords: meaning analysis, semiotic textology, text as complex sign
\end{abstract}

\section{Bevezetés}

Számos olyan tanulmány látott már napvilágot, amelynek témája József Attila valamely versének, szövegének elemzése, igazolva egyúttal valamely nézőpont létjogosultságát a szövegjelentés vizsgálatában.

Az alábbi gondolatmenet egyik oldalról ezeknek a törekvéseknek a sorába tartozik, amennyiben új árnyalatot adhat a költő ismert versének értelmezéséhez. Másik oldalról célom az említett szöveg elemzésével illusztrálni azt, hogy a szemiotikai textológia keretében definiált komplex jelmodell, valamint a jelentéssíkok rendszere milyen információkkal járul hozzá a szöveg jelentésének reprezentációjához. Jelen esettanulmánnyal tehát illusztrálni kívánom a szemiotikai textológiai jelentésleírás hozadékát.

Ezeknek a törekvéseknek a jegyében az alábbiakban elsőként röviden ismertetem a szemiotikai textológia szövegszemléletének azt a legmarkánsabb vonását, amely megkülönbözteti más, szövegekkel foglalkozó tudományokétól; ez megkívánja a konstringencia jelenségének magyarázatát. Ezzel összhangban vázlatosan áttekintem a szemiotikai textológia szemléletére ható fó tudományos irányzatokat, szemléltetve azt az ,áramlatot”, amelybe a szemiotikai textológiai szövegjelentés-felfogás is tartozik. Ezután ismertetem a szemiotikai textológiai szövegjelentés-reprezentációban kiemelkedő szerepet játszó két - egymással összehangolt - 
Dobi Edit:

A szemiotikai textológiai jelentésreprezentáció hozadéka József Attila Mama cimü versének elemzésében

Argumentum 16 (2020), 260-279

Debreceni Egyetemi Kiadó

DOI: 10.34103/ARGUMENTUM/2020/16

részrendszert, a komplex jelmodell komponenseit, valamint a jelentéssíkok rendszerét. Ezek jelentésreprezentációban betöltött funkciója József Attila Mama (1934) címü versének szemiotikai textológiai jelentésvizsgálatában lesz nyomon követhető.

\section{$2 \quad$ Mitől szöveg a szöveg?}

Azoknak a kritériumoknak a meghatározása, amelyek mentén valamely jelszerveződés szövegnek tekinthető, kezdetektől foglalkoztatja a szövegtudományt. A textualitás feltételeiként számon tartott szövegsajátosságokat a szakirodalom több jól ismert, tudományosan megalapozott rendszere pontosan kategorizálja.

Jelen tanulmány keretében - nem hagyva figyelmen kívül a tisztán nyelvészeti szövegkutatás támpontjait és eredményeit - a szöveg használóját tekintem meghatározónak a szöveg (mint komplex jel) jelentésének reprezentációjában. Ebben a megközelítésben a szöveg értelmezője (ahogyan nyilvánvalóan alkotója is) mint egyedi mentális tartalom, illetve mint egyedi mentális müködés van jelen. Ennek a felfogásnak a keretében a textualitás alapja a szöveg befogadójának intuíciója arra vonatkozóan, hogy egy aktuálisan észlelt komplex jel az ő számára szövegként funkcionál-e vagy sem. A befogadó a szóban forgó jelszerveződést akkor ítéli szövegnek, ha a nyelvi (fizikai) formához jelentést és kommunikatív funkciót tud rendelni. Ennek a jelenségnek a jellemzésére vezeti be Petőfi S. János a konstringencia fogalmát: egy adott szöveg akkor tekinthetö konstringensnek, ha a szöveghez aktuálisan hozzárendelt tényállás-konfigurációt a szöveg alkotója, illetve befogadója összefüggőnek és teljesnek ítéli, azaz el tudja fogadni a valóság egy lehetséges szegmenseként. A konstringencia kategóriája tehát a szöveg-összefüggőség egyes síkjait jellemző kategóriák - a kohézió, a konnexitás és a koherencia - sorába illeszkedik mint a jelhasználónak a szövegjelentésre vonatkozó benyomása/ítélete (vö: konstringenciaítélet). Korábbi elképzeléseket felülírva több szemiotikai textológiai esettanulmány alátámasztja, hogy a szövegkoherencia egyedüli feltétele a konstringencia, azaz egy szöveg textualitása közvetlenül nem függ össze sem a nyelvi elemek jelentéskapcsolatával (kohéziójával), sem pedig a nyelvi sík grammatikai összefüggőségével (konnexitásával). ${ }^{1}$

A befogadó intuícióját a szövegről és a szöveghez rendelhető tényállás-konfigurációról számos körülmény befolyásolja. Ezek közül kiemelendők egyrészt a pillanatnyi benyomások, másrészt a befogadó háttértudása (ismeretei, adottságai, képességei) egymással ok-okozati összefüggésben. A pillanatnyi benyomások között kiemelendők a szöveg fizikai formájáról, a szöveg szemiotikai szerveződéséről, a kommunikációs helyzetről, a közlő feltételezett szándékáról létrejövő intuíciók. A befogadó háttértudása többféle tartalmat foglal magába; körvonalakban a szövegtípusokra vonatkozó ismereteiböl, a kommunikációs helyzetekre vonatkozó tapasztalati tudásából, szociokulturális beidegződéseiből, szokásaiból, valamint neveltetéséből, egyéni mentális adottságaiból áll. Az utóbbi tényezővel kapcsolatban érdemes figyelembe venni, hogy a befogadó egyéni mentális fejlettsége nagyban befolyásolja azokat a képességeit, amelyeket a kognitív tudomány szándéktulajdonításnak, perspektíva-elemzésnek, perspektívaváltásnak nevez, és amelyek nagy szerepet játszanak a nem szó szerinti jelentés (ide értve a metaforákat is), az irónia, a gúny, a humor, valamint a szimbólumok értelmezésében.

A konstringencia meghatározásához lásd: Petőfi S. 2004. A konstringenciának a szöveg szemiotikai textológiai jelentésreprezentációjában betöltött szerepével több tanulmányban foglalkoztam: lásd többek között Dobi 2012, 2015, 2016, 2019. 
Dobi Edit:

A szemiotikai textológiai jelentésreprezentáció hozadéka József Attila Mama cimü versének elemzésében

Argumentum 16 (2020), 260-279

Debreceni Egyetemi Kiadó

DOI: 10.34103/ARGUMENTUM/2020/16

\section{A szöveg szemiotikai textológiai megközelítése}

Amikor a kutatás tárgya a szöveg - akár általánosságban véve, akár konkrét szövegpéldányként -, tisztázandó a kiindulópontként szolgáló szövegfogalom, valamint vele szoros összefüggésben a kutatói nézőpont.

Jelen keretben a szöveg jelenségének és a szövegjelentés magyarázatának szemiotikai textológiai felfogására hagyatkozom, eltekintve attól, hogy teljességre törekedve értékelö bemutatását adjam a szövegkutatás azon irányzatainak, amelyek hatottak, illetve hatnak a szemiotikai textológiai szövegszemléletre. ${ }^{2}$

\subsection{Röviden a szemiotikai textológiai szemlélet fö forrásairól}

Pusztán néhány forrást emelek ki azok közül, amelyek véleményem szerint több szövegkutató, közöttük Petőfi S. János figyelmét is ráirányíthatták a jel használójának szerepére a jelentésvizsgálatban: ${ }^{3}$

- M. A. K. Halliday szisztémikus-funkcionális grammatikája, amelynek alapvető tétele, hogy a nyelv funkciója a jelentés megformálása, miközben a nyelv társadalmi interakciókban létezik (Halliday 1968, 1985).

- Werner Kallmeyer beszédaktus-elméletben gyökerező modellje, amelynek keretében a szöveg mint müködés, illetve mint a befogadóra irányuló cselekvés van jelen: a szöveg ,a beszédaktusokban megjelenő nyelv" (Kallmeyer 1974: 24).

- M. A. K. Halliday és Ruqaiya Hasan kohézió-elmélete, amely rávilágít arra, hogy a jelentés folytonossága a mondatszerveződésen túlmutató jelenség: „a kohézió a szöveg egy elemének a szemantikai viszonya egy másikhoz, amely az elsőnek az értelmezéséhez szükséges" (Halliday \& Hasan 1976: 8), ezzel együtt a kommunikáció szempontjából fó szemantikai egység a szöveg, amelynek strukturális sajátossága, hogy mondatok formájában valósul meg.

- Teun A. van Dijk kései összegzései, amelyekben elötérbe kerül az intezionális és az extenzionális szemantika szerepe a szöveg jelentésének vizsgálatában a korábbi generatív szintaktikai szemlélet rovására (van Dijk 1977/1982, 1977, 1980).

- Robert-Alain de Beaugrande és Wolfgang U. Dressler kognitív irányba mutató szemlélete, amely a 60-as évektől részben egymás mellett, részben egymás ellen ható szövegfelfogások tanulságának tekinthető. Egyik oldalról a strukturalista és a generatív mondattanból sarjadó szövegszemlélet, másik oldalról a tisztán kommunikáció-központú irányzatok után szövegfelfogásuk fordulatot hozott: a statikus szövegfogalmat dinamikus szövegfelfogás váltotta föl, így a szöveget már nem az alkotási folyamat eredményének tekintették, hanem alkotási és befogadási (azaz kognitív) folyamatnak. Ezzel összhangban minden megnyilatkozás szövegnek minősül, amely megfelel a következő hét feltételnek: kohezív; koherens; szándékolt; a hallgató által elfogadható; hírértéke van; az adott szituációhoz illeszkedik; illetve kapcsolatot

2 A szemiotikai textológia kialakulásának és fejlődésének tudományos kontextusával kapcsolatban részletesen lásd Dobi 2011-et.

3 Nem említem itt azokat a támpontokat, amelyek - bár közvetetten nyilvánvalóan szerepet játszottak a kognitív szemlélet megerösödésében - elsősorban a nyelvi konstrukciókra, a konstrukció és a funkció összefüggésére összpontosítottak (vö. pl. Daneš 1970/82, Daneš \& Viehweger 1976, 1977). 
Dobi Edit:

A szemiotikai textológiai jelentésreprezentáció hozadéka József Attila Mama cimü versének elemzésében Argumentum 16 (2020), 260-279

Debreceni Egyetemi Kiadó

DOI: 10.34103/ARGUMENTUM/2020/16

teremt más szövegekkel, szövegtípusokkal, azaz megfelel az intertextualitás kritériumának (de Beaugrande \& Dressler 1981). ${ }^{4}$

- Wolfdietrich Hartung kommunikáció-központú szövegfelfogása, amelynek keretében a szöveg része a kommunikációs tevékenységnek (Hartung 1983).

- Charles W. Morris szemiotikája, amely a kommunikációs helyzetet jóval tágabb tartományként feltételezi, mint a szöveget közvetlenül meghatározó kontextust.

Az itt vázlatosan felsorolt irányzatok szemlélete kognitív irányba mutat, lehetővé téve a szövegnek mint (szemantikai és grammatikai szerveződésü) produktumnak és a szövegnek mint kognitív folyamatnak egyidejü, homogén elméleti és módszertani keretben történő vizsgálatát. $^{5}$

\section{$3.2 \quad$ A szöveg mint komplex jel}

A szövegjelentés kognitív szemléletü megközelítése szükségessé teszi a komplexjel-felfogás kiterjesztését a szövegre is. A komplexitás a szöveg jeltermészetében legnyilvánvalóbban Petőfi S. János szemiotikai szövegfelfogásában jelenik meg.

A szemiotikai textológia a szövegek reprezentációjában a nyelvi megformáltság és az ábrázolt valóság párhuzamos leírását teszi lehetővé úgy, hogy modelljében szerepet kap az intenzionális és az extenzionális jelentés reprezentációja is (az intenzió és az extenzió carnapi értelmében), ahol az intenzió a nyelven belüli jelentésszerkezetet, az extenzió pedig a jelentéses nyelvi elemek valóságvonatkozását jelzi. Petőfi S. az extenzionális jelentés modellálásával a szöveg befogadásának és értelmezésének körülményeit is bevonja a tudományos vizsgálatba, ezáltal a szövegnek mint komplex jelnek a leírása átlépi a nyelvészeti szövegvizsgálat kereteit.

Ezzel összhangban jön létre a szemiotikai szövegfogalom, amelynek meghatározó pillérei a következöek:

- A szöveg nyelvi, vagy dominánsan nyelvi objektum.

- A szövegség (szöveg értéküség) az alkotó, illetve a befogadó ítélete.

- Az alkotói, illetve a befogadói ítélet közege az alkotó, illetve a befogadó által kommunikációs helyzetnek ítélt aktuális kommunikációs szituáció.

- A szöveghez az alkotó, illetve a befogadó által valós vagy vélt kommunikatív funkció rendelhetö.

- A valós vagy vélt kommunikatív funkció teljesülésének az a feltétele, hogy az alkotó, illetve a befogadó általi interpretációfolyamat eredményeként a szöveghez összefüggőnek és teljesnek ítélhetö tényállás-konfiguráció legyen rendelhető.

- A szöveg által feltételezhetően kifejezett tényállás-konfigurációnak (az alkotó, illetve a befogadó által vélt) összefüggősége és teljessége miatt a szöveg nyelvi szerveződése is összefüggő és teljes, vagy az alkotó, illetve a befogadó interpretációs mủveletei révén azzá tehető.

4 A kritériumok között szereplő kulcsfogalmak értelmezésével kapcsolatban értékes áttekintések és okfejtések olvashatók az Officina Textologica sorozat 16. kötetében, amelyek az alapvető szövegtani fogalmak alkalmazásának szemléletfüggő sajátosságait járják körül (Dobi szerk.: 2011).

5 A szövegekkel foglalkozó tudományok történeti áttekintése a szövegjelentés leírása szempontjából releváns szemléletbeli sarokpontok bemutatásával legrészletesebben Tolcsvai Nagy 2001-ben olvasható, amelyhez értékes forrás többek között Bókay 1979. 
Dobi Edit:

A szemiotikai textológiai jelentésreprezentáció hozadéka József Attila Mama cimü versének elemzésében

Argumentum 16 (2020), 260-279

Debreceni Egyetemi Kiadó

DOI: 10.34103/ARGUMENTUM/2020/16

\subsection{A komplex jel összetevöi}

A szemiotikai textológiai komplex jelmodell felépítése a szöveg mint komplex jel jelentésreprezentációjának a szolgálatában áll: a jelet Petőfi S. Saussure-höz hasonlóan egy jelölő és egy jelölt viszonyaként értelmezi, a verbálisan megformált szöveg és az általa jelölt valóságos tényállás viszonyaként. Mivel a nyelvi megformáltság és a valóságvonatkozás párhuzamos reprezentálására törekszik, ehhez a szándékhoz idomul komplexjel-értelmezése: a jelnek mind a jelölő, mind a jelölt összetevőjét elemeire bontja, hogy a szövegleírás egyes aspektusainak tárgyát ezekkel a részkomponensekkel adhassa meg. ${ }^{6}$

Mivel a szemiotikai textológiai jelelmélet a jelértelmezésbe bevonja a jel használóját is, mind a jelölő, mind pedig a jelölt összetevőt kognitív aspektusból közelíti meg: ezáltal mindkettő szétválik egy objektivált (vagy objektiválható) és egy az alkotó, ill. a befogadó által leképezett síkra.

A szöveg megjelenési formája, amely független a befogadótól és a kommunikációs helyzet összes tényezőjétől, a vehikulum. Az említett tényezőktől szintén független valóságvonatkozás a relátum. Amikor ezekről a szövegalkotás vagy -befogadás folyamatának függvényében beszélünk, akkor a megjelenési formának is, és a valóságvonatkozásnak is a mentális leképeződéséröl van szó: a vehikulum-imágóról és a relátum-imágóról. Ebben az összefüggésben tehát a vehikulum-imágó azt a mentális képet jelenti, amely az alkotóban és/vagy a befogadóban a nyelvi alakulat fizikai megjelenési formájáról létrejön; a relátum-imágó pedig a fizikai megjelenési formában feltehetően kifejezésre jutó tényállásnak a mentális képe, amelyet az alkotó létrehoz, és/vagy amely a befogadóban létrejön.

Mindkét mentális képhez hozzárendelhető a természetüknek megfelelő felépítés: a vehikulum-imágóhoz a formális szerveződés (formáció-imágó); a relátum-imágóhoz pedig az az értelem (szenzus-imágó), amely a vehikulum-imágóval és a benne feltehetőleg kifejezett tényállás-konfigurációval (relátum-imágóval) hozható kapcsolatba. A formáció-imágó a szöveg fizikai megnyilvánulását létrehozó formai egységeknek és átfogó formai sajátosságoknak az összességét jelenti, tehát egyrészt fizikai síkon valósul meg (vizuálisan betütípus, sorhosszúság, szedéstípus, sorköz, ritmus stb., akusztikusan hangok, prozódiai mintázatok, beszédtempó stb. formájában); másrészt szemiotikai síkon (fonológiai, morfoszintaktikai stb. jelenségekben). Előbbi a figura, utóbbi pedig a notáció. A szenzus-imágó - a formációhoz igazodva - szintén két síkon nyilvánul meg. A fizikai megjelenési formával kapcsolatba hozható értelem az egyes lexémák értelméből és a morfoszintaktikai elemek viszonyjelentéseiböl áll, azaz független az aktuális kontextustól, a kommunikáció körülményeitöl és tényezőitől, beleértve magát a befogadót is. A szövegben feltehetőleg kifejezésre jutó tényállással kapcsolatba hozható értelem arra a tényállásra utal, amelyet az alkotó az adott nyelvi környezetben, az adott kommunikációs helyzetben kifejez, és/vagy amely a befogadóban az adott nyelvi környezetben, az adott kommunikációs helyzetben létrejön; vagyis ez a befogadó percepciójának és interpretációjának az eredménye, tehát a szöveg egyedi és egyszeri jelentése.

6 Bár a szemiotikai textológiai szövegszemlélet vonatkozásában lényeges szerepe van az említett elméleti kerettel összhangban álló percepciómodellnek és a kommunikációs folyamatról alkotott elképzelésnek is, ezekkel jelen tanulmány keretében nem foglalkozom; a szöveg nyelvi megformáltságának és valóságvonatkozásának párhuzamos megközelítésére hagyatkozom, amely a komplex jel modelljének és a jelentéssíkok rendszerének ismeretét kívánja meg. 
Dobi Edit:

A szemiotikai textológiai jelentésreprezentáció hozadéka József Attila Mama cimü versének elemzésében

Argumentum 16 (2020), 260-279

Debreceni Egyetemi Kiadó

DOI: 10.34103/ARGUMENTUM/2020/16

\subsection{A jelentésreprezentáció alapjául szolgáló jelentésfelfogás}

A szemiotikai textológia keretében értelmezett jelentésmodell kiindulópontja az extenzionális és az intenzionális jelentés közötti különbségtétel, ahol az intenzionális jelentés a nyelvi síkhoz kötődik, az extenzionális jelentés pedig a nyelvi vetület valóságvonatkozásaként kezelendő (a fogalmak carnapi értelmezésében). Az extenzionális jelentés vizsgálata kapcsán olyan jelenségekkel, körülményekkel is számolunk, amelyek a szövegelemzés tudományos keretét kitágítják a nyelvtudományon kívülre.

\subsubsection{A jelentéssíkok szemiotikai textológiai rendszere}

Ez az alapállás Petőfi S. Jánost a jelentés három síkjának elhatárolására készteti, amelyekhez különböző befogadói müveletek során lehetséges hozzáférni, és amelyek rendszerét később többféle szövegtípusba tartozó szövegek vizsgálata nyomán - egy negyedik jelentéssíkkal egészítettem ki (l. Dobi 2013: 18). Ennek végeredménye lett az értelmi, a referenciális, a kommunikatív és az asszociációs jelentéssíkból álló komplex jelentésfelfogás.

Az értelmi jelentés síkját Petőfi S. verbalizált fogalmi jelentésként definiálja, amely nyelviszemantikai értelmező folyamat eredménye, melynek során a szöveg nyelvi megformáltságához feltételezhetően hozzárendelhető jelszerveződés alapján a befogadó létrehozza a nyelvi megformáltság alkotóelemeihez rendelt jelentésegységek szerveződését. Ezzel a müvelettel kapcsolatban két - egymással törvényszerüen összefüggő - eljárást kell kiemelnünk:

- a szöveg kiegészítését a nyelvileg kifejtett egységek alapján kikövetkeztethető, nyelvileg nem kifejtett egységekkel;

- olyan, világra vonatkozó ismeretek illetve feltevések (tudáskeretek, forgatókönyvek) alkalmazását, amelyeket a konvencionális szótári jelentéseket alapul vevő jelentéseken kívül alkalmazunk.

A referenciális jelentés a szöveg fizikai megformáltságához a lineáris és a hierarchikus kompozíció értelmezése alapján rendelhető hozzá. A kompozíció alkotóelemei nominális és predikatív referenciájú egységek: a nominális szerveződés értelmezésekor a befogadó a személyeket, a tárgyakat, a tényállásokat és a közöttük lévő korreferenciális viszonyokat azonosítja; a predikatív szerveződés értelmezésekor azoknak az igei vagy más szófajú predikátumoknak a hálóját határozza meg a közöttük lévő korreferenciális relációkkal együtt, amelyekkel a szöveg nyelvi megformálása a tényleges vagy feltételezett valóságmozzanat tényleges vagy feltételezett tényállásait reprezentálja.

A referenciális jelentés értelmezéséhez hozzátartozik még a szövegnek - a befogadó számára elfogadható - lineáris és hierarchikus szerveződését létrehozó müvelet. Ez a mozzanat a nyelvileg explicit tényállások között értelmez elvárásoknak megfelelö összeférhetőségi viszonyokat, illetve olyan lineáris szerveződéseket, amelyek az ezeket a viszonyokat kifejező verbális elemekből jönnek létre.

$\mathrm{Az}$ ismertetett folyamat következményeként a befogadó olyan referenciális jelentést értelmez, amelynek alapján a nyelvi szerveződés formái által kifejezett valóságmozzanat mentális képét el tudja fogadni egy összefüggő, konstringens valóságdarab mentális képeként.

A kommunikatív jelentés értelmezése olyan müvelet, amely egy adott nyelvre vonatkozik. Egy adott szöveg kommunikatív jelentése egyrészt a szöveg mondatainak belső elrendezésétől és prozódiájától függ, másrészt a mondatok szövegbeli lineáris szerveződésétől. Erre a kétféle szerveződésre az egyes nyelvek eltérő lehetőségeket és kötöttségeket értelmeznek, amelyek a lineáris elrendezésekkel szoros összefüggésben meghatározzák a rájuk jellemző prozódiai 
Dobi Edit:

A szemiotikai textológiai jelentésreprezentáció hozadéka József Attila Mama cimü versének elemzésében

Argumentum 16 (2020), 260-279

Debreceni Egyetemi Kiadó

DOI: 10.34103/ARGUMENTUM/2020/16

struktúrákat is. Mivel a magyar nyelvben egy szerkezeti egységen belül az összetevők általában többféle elrendezésben állhatnak, és az egyes sorrendi variációkhoz eltérő prozódiai struktúrák is tartoznak, a jelentésreprezentáció szempontjából informatív, hogy a lehetséges sorrendi variációk közül melyik elrendezés, illetve melyik prozódiai struktúra választódik ki egy adott szöveghelyen. Petőfi S. János ezt az informativitást nevezi ,,a szóban forgó alapegység, illetőleg alapegység-lánc kommunikatív jelentésének” (Petőfi S. 2008).

Az asszociációs jelentéssík az egyes szövegmondatokhoz feltételezhetően hozzárendelt tényállásokból és a közöttük - a kollektív és az egyéni háttértudás alapján - egyéni asszociáció révén értelmezhető viszonyokból tevődik össze. A hangsúly itt az asszociáció aktuálisan adott befogadóra specifikusan jellemző természetén van. Az asszociációs jelentés síkja természetesen nem független a másik három jelentéssík egyikétől sem. Szükségszerüen és egyértelmüen áll összefüggésben az értelmi és a referenciális jelentéssíkkal, mivel a mentalizáció folyamatában a kollektív és az egyéni háttértudást is az egyes nyelvi elemekhez rendelhető referenciális értékek aktiválják. A szóban forgó jelentéssík a kommunikatív jelentés síkjával pedig azáltal függ össze közvetlenül, hogy a szövegmondatok különböző sorrendi változataihoz tartozó eltérő prozódiai struktúrák különböző értelmi mintázatokat fejeznek ki, aminek révén a sorrendi változatok eltérő asszociációk kiindulópontjai lehetnek.

A már meglévő három jelentéssík kiegészítéseként az asszociációs jelentéssík definiálását az teszi szükségessé, hogy azt, hogy bizonyos sajátos esetekben miképpen állnak össze koherens szöveggé a szövegmondatok, más esetekben pedig miért nem, az értelmi, a referenciális és a kommunikatív jelentéssíkból álló rendszer nem képes explicit módon magyarázni. Úgy gondolom, hogy hasonló a helyzet az olyan szövegek esetében is, amelyek jelentésreprezentációjában a poétikai, ill. az esztétikai érték fontos szerephez jut.

A jelentés szemiotikai textológiai reprezentációjában az egyes jelentéssíkok szoros összefüggésben állnak a komplex jel komponenseivel:

- az értelmi jelentés megegyezik a vehikulum-imágóval (vagyis a nyelvi megformálás mentális képével) kapcsolatba hozható értelemmel,

- a referenciális jelentés mindkét szenzus-imágó-komponenssel összefüggésben áll, mivel a referenciális jelentés síkján domináns korreferencialáncok elemei a konvencionális szótári jelentések egyéni mentális leképezései,

- a kommunikatív és az asszociációs jelentéssík erőteljes kontextuális befolyásoltsága és szubjektív asszociációk általi meghatározottsága okán a relátum-imágóval (a szöveg által feltehetőleg kifejezett tényállás mentális leképezésével) kapcsolatba hozható értelemmel áll összefüggésben.

\subsubsection{A jelentésreprezentáció kiindulópontja}

Az interpretáció alapja az értelmező jelentésreprezentáló szándéka, amelyhez támpontként az értelmező adott interpretációs helyzetbeli, adott pillanatban rendelkezésre álló tudása szolgál. Ezt a tudást Petőfi S. János tudásbázisnak nevezi. ${ }^{7}$

Petőfi S. a szövegjelentés reprezentációjában felhasznált tudástípusok rendszerezésével szoros összefüggésben típusokba rendezi az interpretáció jellegzetes formáit is. Ahogyan a tudásbázisok tipológiája sem, úgy az interpretációtípusok rendszere sem lehet teljes, de a tudásbázisok rendszerezésére irányuló törekvéssel összhangban láttatni kívánja, hogy bizonyos szempontok mentén az értelmező szándék is típusokba rendezhető. Az interpretáció típusai bizonyos általánosnak tartható jellemzők mentén kategorizálhatók (1. Petőfi S. 2004: 94-95). 
A szemiotikai textológia keretében a tudásbázisok három szektorba rendezhetők: a tudás/hiedelem, a feltevések és az elvárások szektorába az interszubjektivitás csökkenő foka szerint. Ez a megközelítés arra hívja fel a figyelmet, hogy a jelentésreprezentációt alapjaiban határozza meg a kommunikáló felek tudásbázisai közötti megfelelés, illetve átjárhatóság. A tudásbázisokat Petőfi S. informatív konfigurációba rendezi:

- A tipológiai bázis a szövegtípusokra és a kommunikációs helyzet típusaira vonatkozó tudást és feltételezéseket foglal magában, az interpretációfolyamatban kitüntetett szerepe van. Az, hogy az értelmező az értelmező műveletekben a háttértudásának mely elemeit választja ki és használja, attól függ, hogy az éppen értelmezett szöveget mely szövegtípusba sorolja, valamint hogyan ítéli meg az adott kommunikációs helyzet típusát.

- Az interpretáció centrális bázisa a tudás és feltevések összes típusát tartalmazza médiumspecifikusan rendszerezve. ${ }^{8}$

- A tudásbázisok rendszere tartalmaz ún. lokális bázisokat is, amelyek elemei az interpretáció centrális bázisából kiválasztott tudáselemek között teremtenek kapcsolatot.

A szöveghez mint komplex jelhez rendelhető jelentés reprezentációja szorosan összefügg tehát azzal a tudással, melyet az aktuális jelentésleképezésre jellemző kognitív müveletek során a befogadó felhasznál, valamint azokkal a logikai kapcsolatokkal, amelyeket a befogadó a tudáselemek között felismer, rekonstruál, feltételez stb. (Petőfi S. 2004: 104-106).

\section{József Attila Mama (1934) címú versének szemiotikai textológiai jelentésrep- rezentációja}

A József Attila-vershez rendelhető jelentés szemiotikai textológiai elemzésének módszertani kerete egyik oldalról a fentebb bemutatott komplexjel-modell, másik oldalról a jelentéssíkok rendszere, figyelembe véve, hogy ezek ismerete mellett hasznos tudást nyújtanak a jelhasználó háttértudásának jellemzésére szolgáló kategóriák. Ez a megállapítás különösképpen érvényes, amikor az elemzés tárgya ismert magyar költő népszerü témát kibontó - már az általános iskolai oktatás keretében feldolgozott - költeménye. A vers értelmezője számára elsődleges benyomás a szöveg típusa, amely az értelmező befogadói magatartását lírai, filozófiai tartalom feldolgozása felé tereli, amelyhez tartozó mentális tartomány fő elemei a család, az anya-gyermek viszony, a nők által végzett házimunka kategóriái közül aktiválódnak.

\subsection{A komplex jel összetevöi József Attila Mama címü versének tükrében}

A vers vehikulumához, azaz a befogadótól és a kommunikációs helyzet összes tényezőjétől független megjelenési formájához - filozófiai ételemben - nem lehetséges hozzáférni, mivel a hozzáférés pillanatában vehikulum-imágóvá változik.

A vers vehikulum-imágója az a megjelenési forma, amit észlelünk - jelen esetben látunk József Attila Mama címü verseként, és amit fel tudunk idézni emlékeinkben, amikor már

\footnotetext{
A szemiotikai textológiai jelfelfogás számol a nem verbális jelekhez rendelhető jelentéssel is, tekintve, hogy a különböző médiumokhoz rendelhető jelentés reprezentációja a befogadó eltérő mentális folyamatait feltételezi. Ennek értelmében válik külön a tágan értelmezett szemiotikai textológiai jelfogalom kapcsán a (tisztán vagy dominánsan nyelvi) szöveg és a (nyelvi jelekkel nem operáló) kommunikátum kategóriája.
} 
Dobi Edit:

A szemiotikai textológiai jelentésreprezentáció hozadéka József Attila Mama cimü versének elemzésében Argumentum 16 (2020), 260-279

Debreceni Egyetemi Kiadó

DOI: 10.34103/ARGUMENTUM/2020/16

közvetlenül nem érzékeljük a vers fizikai megnyilvánulását. Az elemzésre választott szöveg az alábbi fizikai formában jelent meg: ${ }^{9}$

\section{József Attila}

Mama

Már egy hete csak a mamára gondolok mindig, meg-megállva.

Nyikorgó kosárral ölében,

ment a padlásra, ment serényen.

Én még őszinte ember voltam, ordítottam, toporzékoltam.

Hagyja a dagadt ruhát másra.

Engem vigyen föl a padlásra.

Csak ment és teregetett némán, nem szidott, nem is nézett énrám $\mathrm{s}$ a ruhák fényesen, suhogva, keringtek, szálltak a magosba.

Nem nyafognék, de most már késő, most látom, milyen óriás ő szürke haja lebben az égen, kékítőt old az ég vizében.

A vers befogadó által felidézett mentális képének a szerkezete, vagyis a formáció-imágó:

- A fizikai megjelenés mentális képének a szerkezete (figura): a betüformákból létrejövő vizuális mintázat, amely fehér alapon fekete formák különböző komplexitású szerveződéséből áll a betűnyi formától a szó- majd sorhosszúságú alakzatokon át a versforma egészéig. Általánosságban, így az elemzett szöveg esetében is az aktuálisan befogadott objektum fizikai megjelenésének a szerveződéséről létrejövő mentális kép hat a jelentésreprezentáció folyamatára. A fizikai forma - versszakokra való tagolódást modelláló - szerveződése a befogadóban aktiválja a versformára vonatkozó tapasztalati tudást, amelynek birtokában az értelmezői attitüd a lírai szövegekre jellemző interpretációs törekvések és elvárások irányába tolódik el.

- A fizikai megjelenés mint szemiotikai objektum mentális képének a szerkezete (notáció): az elemi nyelvi jelekből szerveződő komplexebb nyelvi alakulatok percepciója révén a befogadó benyomása a József Attila-verset alkotó nyelvi kompozícióegységekről. A versről mint szemiotikai jelszerveződésről alkotott befogadói benyomás, azaz a vers szemiotikai jelszerveződésének mentális leképezése szintén hatással van a jelentésreprezentáció folyamatára azáltal, hogy a befogadó értelmező magatartását abba a tartományba tereli, amely megfelelő a befogadó által észlelt jelkomplexitáshoz rendelhető jelentés leképezéséhez. József Attila versének négy versszaka összesen hét mondatból áll, amelyeket jellemzően alárendelő szószerkezetek alkotnak. A mondatokon belüli viszonyok a magyar nyelv szabályainak megfelelően vannak

Forrás: József Attila összes versei (1972). A verseket összegyüjtötte és a szöveget gondozta Szabolcsi Miklós. Budapest: Szépirodalmi Könyvkiadó, 302. 
jelölve (mamára gondolok, ment serényen, hagyja a ruhát, dagadt ruhát, hagyja másra stb.), az egyes mondatok, mondattömbök vagy versszakok közötti szemantikai és grammatikai relációkat nem jelzik kötőszavak.

A vers relátumához, azaz a vers által jelölt valóságdarabhoz (ahhoz a jelentéshez, amiröl a vers objektíve szól) - a vehikulumhoz hasonlóan - nem férhetünk hozzá.

A relátum-imágó a vers jelölőjében feltehetően kifejezésre jutó tényállásnak a befogadóban kialakult mentális képe, vagyis az a képi sík, amelyet a vers percepciója során valóságvonatkozásként (feltehetően kifejezett tényállásként) mentálisan egyénileg vizualizálunk. Ez voltaképpen az a „film”, amelyet a képzeletünk ,vetít” a vers befogadása során. Szereplöi egy édesanya (ó) és egy fiúgyermek (én) azokkal a gesztusokkal és cselekményekkel, amelyek a vers dinamikus jelentésủ szavaiban jutnak kifejezésre (meg-megállva, ment serényen, ordítottam, toporzékoltam stb.).

A vers szenzus-imágója az az értelemszerveződés, amely József Attila Mama címü versének fizikai megformálása és a hozzá rendelhető tényállás alapján jön létre a befogadóban.

- A fizikai megjelenési formával kapcsolatba hozható értelem a vers lexémáinak értelméből és a közöttük lévő viszonyjelentésekből áll, amit a vers intenzionális jelentésének tekintünk, amely független az aktuális kontextustól, a kommunikációs körülményektől, és - ami jelen dolgozat témája szempontjából különösképpen figyelmet érdemel - független attól a világra vonatkozó tudástól is, amely a mindenkori befogadó rendelkezésére áll a vers értelmezésének pillanatában. József Attila versének kapcsán ezen a ponton egy olyan valóságosként elképzelhető tényállásegyüttesről van szó, amelynek alkotóelemeit a vers egyes verbális összetevőihez anélkül rendeljük hozzá, hogy az adott kontextusban aktiválható háttértudást felhasználnánk (például a költő személyiségéről, édesanyjához füződő viszonyáról, a család életéről stb.).

- A versben feltehetöleg kifejezésre jutó tényállással kapcsolatba hozható értelem arra a tényállásra utal, amelyet a költő az adott nyelvi környezetben, az adott kommunikációs helyzetben kifejez, és/vagy amely a befogadóban az adott nyelvi környezetben, az adott kommunikációs helyzetben létrejön. Ez tehát a vers extenzionális jelentése, amely a szöveg témájához kapcsolódó háttértudás birtokában az értelmező egyedi és egyszeri jelentésreprezentációja. Ebben a müveletben a József Attila-kutatások tudományos eredményeire vonatkozó ismereteink, valamint a témával kapcsolatos - vagy az alapján asszociált - egyéni élményvilágunk, emlékeink, érzelmeink stb. egyaránt szerephez jutnak.

\subsection{A jelentéssikok elemzése József Attila Mama címü versében}

\subsubsection{Az értelmi jelentéssík}

Az értelmi jelentéssík reprezentációja nyelvi-szemantikai értelmezés következménye, azé a müveleté, melynek során a befogadó a vers nyelvi formájának felépítését követve a nyelvi elemekhez hozzárendeli a jelentés-egységek szerveződését, amibe beletartoznak a lexikai jelentések és a morfoszintaktikai viszonyjelentések is. A szóban forgó jelentéssík leképezése a befogadótól a következő két müvelet végrehajtását kívánja:

- a szöveg nyelvileg kifejtett egységei alapján a szöveg kiegészítését nyelvileg ki nem fejtett egységekkel;

- fogalmi sémák (tudáskeretek, forgatókönyvek) alkalmazását, amelyek a vers jelentéséhez valamilyen módon kapcsolódó, rendszerezett világra vonatkozó ismereteket, feltevéseket, tudáselemeket tartalmaznak. 
Az első müvelet eredménye az alábbi szövegváltozat (amelyben dőlt betütípussal az eredeti szöveg, álló formátumban a kiegészítések olvashatók):

Már egy hete csak a mamára gondolok (én, József Attila) mindig, meg-megállva. Nyikorgó kosárral ölében (az övében, az anyáméban, az enyémében, József Attiláéban), ment (anyám, az enyém, József Attiláé) a padlásra, ment (anyám, az enyém, József Attiláé) serényen.

Én (József Attila) még őszinte ember voltam (már nem vagyok (?)), orditottam (én, József Attila), toporzékoltam (én, József Attila).

Hagyja (anyám, az enyém, József Attiláé) a dagadt ruhát másra (önmaga, az anyám - az enyém, József Attiláé - helyett).

Engem (József Attilát) vigyen (ő, az anyám, az enyém, József Attiláé) föl a padlásra.

Csak ment (anyám, az enyém, József Attiláé) és teregetett (anyám, az enyém, József Attiláé) némán, nem szidott (anyám, az enyém, József Attiláé) (engem, József Attilát), nem is nézett (anyám, az enyém, József Attiláé) énrám (József Attilára)

$s$ a ruhák fényesen, suhogva,

keringtek, szálltak a magosba.

Nem nyafognék (én, József Attila), de most (amikor már nem vagyok én, József Attila, őszinte ember) már késő,

most (amikor már nem vagyok én, József Attila, őszinte ember) látom (én, József Attila), milyen óriás ö (anyám, az enyém, József Attiláé) -

szürke haja (anyámé, az enyémé, József Attiláé) lebben az égen,

kékitőt old (anyám, az enyém, József Attiláé) az ég vizében.

Az értelmezés másik mentális müvelete néhány jól körvonalazható fogalmi séma elemeit aktiválja a befogadóban. A statikus jelentésü elemek közül a család tudáskerete (anya, gyermek, anya és fiú stb.), a gyermek érzelmeit és vágyait magában foglaló tudáskeret, illetve a ház tudáskerete (padlás) választódik ki a mentális lexikon kategóriái közül. A dinamikus jelentés síkján a házimunka forgatókönyvébe, valamint a gyermeki kommunikáció, önkifejezés forgatókönyvébe tartozó elemek jutnak szerephez a szöveg értelmi jelentésének reprezentációjában.

\subsubsection{A referenciális jelentéssík}

A vers nyelvi szerveződéséhez rendelhető referenciális jelentés reprezentációja a lineáris és a hierarchikus kompozíció értelmezésén alapszik, amely nominális és predikatív referenciájú egységekből áll.

\subsubsection{A lineáris jelentésszerveződés}

Az alábbi táblázat az elemzett vers szövegének nominális és predikatív referenciális egységeit foglalja össze versszakokra tagolva: 
Dobi Edit:

A szemiotikai textológiai jelentésreprezentáció hozadéka József Attila Mama cimü versének elemzésében Argumentum 16 (2020), 260-279

Debreceni Egyetemi Kiadó

DOI: 10.34103/ARGUMENTUM/2020/16

\begin{tabular}{|c|c|c|c|}
\hline \multirow[b]{2}{*}{$\begin{array}{l}\text { Már egy hete csak a mamára } \\
\text { gondolok mindig, meg-megállva. } \\
\text { Nyikorgó kosárral ölében, } \\
\text { ment a padlásra, ment serényen. }\end{array}$} & \multicolumn{2}{|c|}{ Nominális } & \multirow{2}{*}{ 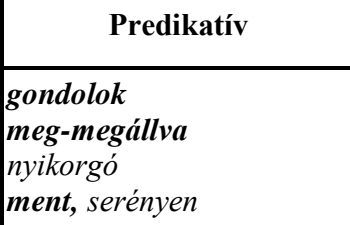 } \\
\hline & $\begin{array}{l}\text { ÉN } \\
\text { ölében } \\
\text { Ö }\end{array}$ & $\begin{array}{l}\text { mamára } \\
\text { olében } \\
\text { kosárral } \\
\text { padlásra }\end{array}$ & \\
\hline $\begin{array}{l}\text { Én még őszinte ember voltam, } \\
\text { ordítottam, toporzékoltam. } \\
\text { Hagyja a dagadt ruhát másra. } \\
\text { Engem vigyen föl a padlásra. }\end{array}$ & \begin{tabular}{|l|} 
Én $\boldsymbol{n}$, ÉN \\
ÉN \\
Ö \\
Engem, Ö
\end{tabular} & $\begin{array}{l}\text { ember } \\
\text { pahát } \\
\text { padlásra }\end{array}$ & $\begin{array}{l}\text { öszinte } \\
\text { orditottam, toporzékoltam } \\
\text { hagyja, dagadt, } \\
\text { vigyen föl }\end{array}$ \\
\hline $\begin{array}{l}\text { Csak ment és teregetett némán, } \\
\text { nem szidott, nem is nézett énrám } \\
\text { s a ruhák fényesen, suhogva, } \\
\text { keringtek, szálltak a magosba. }\end{array}$ & Ö, énrám & $\begin{array}{l}\text { ruhák } \\
\text { magosba }\end{array}$ & $\begin{array}{l}\text { ment, teregetett, } \\
\text { szidott, nézett, } \\
\text { fényesen, suhogva } \\
\text { kering, száll }\end{array}$ \\
\hline $\begin{array}{l}\text { Nem nyafognék, de most már késő, } \\
\text { most látom, milyen óriás ő - } \\
\text { szürke haja lebben az égen, } \\
\text { kékítőt old az ég vizében. }\end{array}$ & $\begin{array}{l}\text { ÉN } \\
\text { ÉN, } \boldsymbol{o} \\
\text { haja }\end{array}$ & $\begin{array}{l}\text { ó, haj } \\
\text { viz, kékitő }\end{array}$ & $\begin{array}{l}\text { nyafognék, látom, óriás, } \\
\text { lebben, old }\end{array}$ \\
\hline
\end{tabular}

A feltüntetett nyelvi elemek tipográfiája az alábbiak szerint értelmezendő:

- dőlttel szerepelnek a nyelvileg kifejtett nominális és predikatív jelentésü egységek,

- közöttük kövérrel emeltem ki azokat, amelyek korreferenciális viszonyban állnak valamely más jelentéses egységgel,

- álló, nagybetűs formátum jelzi a jelentésfolytonosságban szerepet játszó, de nyelvileg nem kifejtett jelentéseket.

A nominális (statikus) jelentés síkján a legmarkánsabb kontinuitást teremtő korreferencialáncok a 'mama' és a 'költői én' jelentése köré szerveződnek, és elsősorban grammatikai utalásokból állnak:

- A 'mama' korreferencialáncába tartoznak a következő kohéziót, illetve konnexitást teremtő elemek: mama, mamára, ö, ölében (az emberi öl és az anya jelentéskapcsolata révén), haja (az emberre, beleértve az anyára vonatkoztatott jelentés révén); valamint az ölében birtokos személyjele, a ment, teregetett, szidott, nézett és a vigyen föl igei személyragja.

- A 'költői én, József Attila' korreferencialáncát szintén részben szemantikai, részben grammatikai utalások alkotják. A József Attila (mint a vers szerzője), az én, engem, énrám nyelvi elemek expliciten biztosítják a 'költői én' jelenlétét a szöveghez rendelhető referenciális jelentés folytonosságában. Grammatikai síkon a gondolok, ordítottam, toporzékoltam, nyafognék igei személyragja erősíti a korreferenciát.

- A nominális referencia síkján megemlítendő a 'ruha' korreferencialánca részleges szóismétlés formájában (ruhát, ruhák), valamint a 'padlás'-é a kifejezés változatlan ismétlésével, illetve a föl igekötő (vigyen föl) és a padlásra asszociatív jelentéskapcsolata révén.

A predikatív (dinamikus) jelentés síkján az anya cselekvését, a költő érzésének a kifejeződését, illetve a ruha mozgását kifejező igék és igei származékok teremtenek jelentésfolytonosságot.

- A 'mama' jelentésre utal grammatikai síkon a ment, hagyja, vigyen, teregetett, szidott, nézett igei személyragja; ugyanakkor a 'mozgás' jelentésmozzanattal jellemezhető szemantikai összefüggés értelmezhető a meg-megállva és a két ment igealak között. 
Dobi Edit:

A szemiotikai textológiai jelentésreprezentáció hozadéka József Attila Mama cimü versének elemzésében Argumentum 16 (2020), 260-279

Debreceni Egyetemi Kiadó

DOI: 10.34103/ARGUMENTUM/2020/16

- Markáns predikatív jelentéssík a vers tartalmi folytonosságának szempontjából a ’József Attilá'-hoz kapcsolódó predikatív jelentések láncolata, amelyet a költő érzelmeit és lelkiállapotát jellemző cselekvéseket kifejező igék alkotnak: orditottam, toporzékoltan, nyafognék.

- A mosott ruha valamely tulajdonságát, mozgását személtető kifejezések által jelölt jelentések (dagadt, fényesen, suhogva, keringtek, szálltak) egymással szintén összefüggésben állnak; az erről az összefüggésröl alkotott befogadói benyomásnak a hátterében olyan tudati tartalék állhat, amelynek birtokában a befogadó a szóban forgó kifejezésekkel jelölt tényállásmozzanatokat egy jól formált komplex tényállás részleteiként fogadja el. Ez a tudati tartalék például lehet egy emlékkép a kimosott, először kosárba gyüjtött majd kötélre teregetett, még nedves ruhákról, amelyekbe aztán belekapaszkodik a szél, és amelyek ettől - mint valamiféle zászló a szélben - lobogni, lengedezni kezdenek.

Az ismertetett korreferencialáncokon kívül több apró jelentésrészlet (különféle természetü) kapcsolata hozzájárul ahhoz, hogy a verset értelmező befogadó a vers szövegéhez hozzárendelhető tényállást konstringens tényállásként fogadja el. Ilyenként említhető például a magosba és az égen, a szürke és a kékitö képlékenyebb jelentésviszonya.

\subsubsection{A hierarchikus jelentésszerveződés}

A vers referenciális jelentésegységeinek hierarchikus reprezentációjában a kiindulópont az egyes egységek összeférhetőségének és az ebből adódó rész-egész relációknak az értelmezése. Az elemzett vers fizikai megformálása a figura síkján ,irányítja” a befogadó értelmezői müveleteit a jelentésegységek vertikális szerveződésének felismerésében.

A vertikális kompozíció elemi szemiotikai egységei a szavak, amelyekböl mondatok szerveződnek; ezekből versszakok; a hierarchikus kompozíció csúcsán - a négy versszakból szerveződő - vers áll. Az egyes versszakokhoz rendelhető tényálláskomplexum eltérő számú és komplexitású tényállásmozzanatból épül fel, amelyeket eltérö komplexitású nyelvi-szemiotikai szerveződés jelöl. Az alábbi ábra sematikusan szemlélteti a szerkezeti egységek egymásba épülését a szövegben: az első versszak két mondatból áll, a második háromból, a harmadik és a negyedik versszakot egy-egy mondat alkotja; a szöveg mindegyik mondata szavakból szerveződő struktúra.

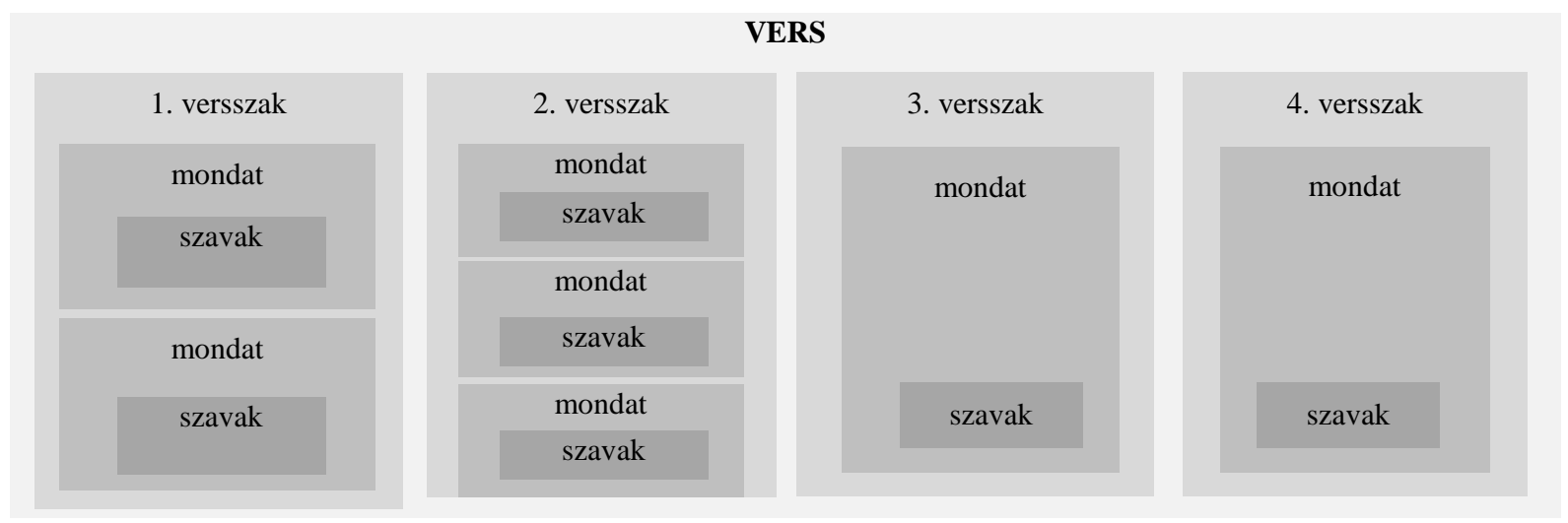


Az ábrázolt szövegszerkezet egységei az alábbi viszonyok mentén szerveződnek összefüggő egésszé.

Az első versszak második mondata az elsőnek értelmezője; ha ezek alárendelő összetett mondat formájában jelennének meg, a második egység az elsőnek értelmező jelzői alárendeltje lenne: a mamára gondolok [...], arra, aki Nyikorgó kosárral ölében ...

A második versszakban az első mondat szemben áll a második és a harmadik mondatból álló tömbbel. Ezt grammatikai síkon az első mondatbeli igealakok egyes szám első személye és múlt ideje (voltam, orditottam, toporzékoltam), valamint a másik két mondat igealakjainak egyes szám harmadik személye és felszólító módja (hagyja, vigyen) közötti különbség jelzi.

A harmadik versszak egyetlen mondat, amely ellentétben áll a második versszakkal. Ennek a relációnak a kifejezője az igék újabb váltása kijelentő módú alakokra (ment, teregetett, szidott, nézett).

A szintén egyetlen mondatként megformált negyedik versszak az első versszakkal együtt keretként értelmezhető. Ezt a benyomást föként az erősíti, hogy a negyedik versszak - bár nem tagolódik két önálló mondatra, mint az első - a benne kifejezett cselekvőket tekintve vele azonos szerkezetü. Mindkét egységben az egyes szám első személyü igalakokat egyes szám harmadik személyüek követik, az utóbbiak mellett az ölében és a haja birtokos személyjele is erősíti az 'én'-nel szemben álló 'ő' jelentést, amely az utolsó versszakban személyes névmás formájában verbalizálódik is.

Az elemzett vers jelentésének - lineáris és hierarchikus szerveződés vizsgálatán alapuló magyarázata jól szemlélteti, hogy miképpen fonódik össze a szöveg jelentésének folytonossága a vertikális kompozícióval a szöveg bizonyos - a jelentés szempontjából központi szerepü - elemei révén.

A szemiotikai textológia felfogásában a referenciális jelentés a valóságnak az a darabja, amelyet egy adott nyelvi forma a befogadó értelmezése szerint jelöl. Ennek a valóságvonatkozásnak a reprezentációja során a befogadó - a fent ismertetett lineáris és hierarchikus jelentésszerveződés értelmezésén kívül - a rendelkezésére álló tudásbázis azon részleteire is hagyatkozik, amelyeket a nyelvi formához rendelhető jelentések és a közöttük fennálló viszonyok mentális feldolgozása aktivál.

$\mathrm{Az}$ elemzett vers referenciális jelentésének reprezentációja bennem mint befogadóban a költő más anya-verseinek egyes részleteit, róluk szóló tudományos véleményeket, valamint bizonyos szakmai (irodalomtudományi, pszichológiai, neurológiai vonatkozású) nézőpontokat aktivál. Ezek mindegyikére azért nem térek ki jelen helyzetben, mert fö törekvésem a szemiotikai textológiai jelentésreprezentáció általános algoritmusának szemléltetése, pusztán néhány versrészlettel szemléltetem a befogadói attitüd komplexitását a Mama címü vers referenciális jelentésének reprezentációja kapcsán.

József Attila több versében reflektált anyjával való kapcsolatára, szülei iránti érzéseire, például: Ad sidera... (1923), [Anyám meghalt...] (1925), Anyám (1931), Kései sirató (1935/1936). A Mama címü vers értelmezési müveletei az én (befogadói) tudati tartalékomból a következő versrészleteket idézik fel, befolyásolva a Mama címü vers fizikai megformáltságához rendelhető referenciális jelentést:

Anyám, ki már a messzi végtelen vagy

s nem gyötrödöl, hogy nincs kenyér megint, 
A szemiotikai textológiai jelentésreprezentáció hozadéka József Attila Mama cimü versének elemzésében Argumentum 16 (2020), 260-279

Debreceni Egyetemi Kiadó

Anyám, ki már a néma végtelen vagy

s borús szemed fiadra nem tekint,

(Ad sidera..., 56)

Anyám meghalt, most nem tudom, hogy viselkedjem

vele szemben,

megfoltozná kabátomat, megnézné milyen szép

vagyok meztelenül,

([Anyám meghalt...], 165)

A bögrét két kezébe fogta,

úgy estefelé egy vasárnap

csöndesen elmosolyodott

s ült egy kicsit a félhomályban-

(Anyám, 248)

Harminchat fokos lázban égek mindig

$s$ te nem ápolsz, anyám.

Mint lenge, könnyü lány, ha odaintik,

kinyujtóztál a halál oldalán.

(Kései sirató, 325)

A Mama címü vers referenciális jelentését az is befolyásolhatja, hogy a befogadó a költeményt illusztrált kötetben olvassa-e. Azt, hogy a képi illusztráció voltaképpen a grafikusmüvész interpretációjának egyfajta lenyomata, jól szemlélteti a két következő illusztráció, amelyek mindegyikét József Attila elemzett költeménye ihlette:

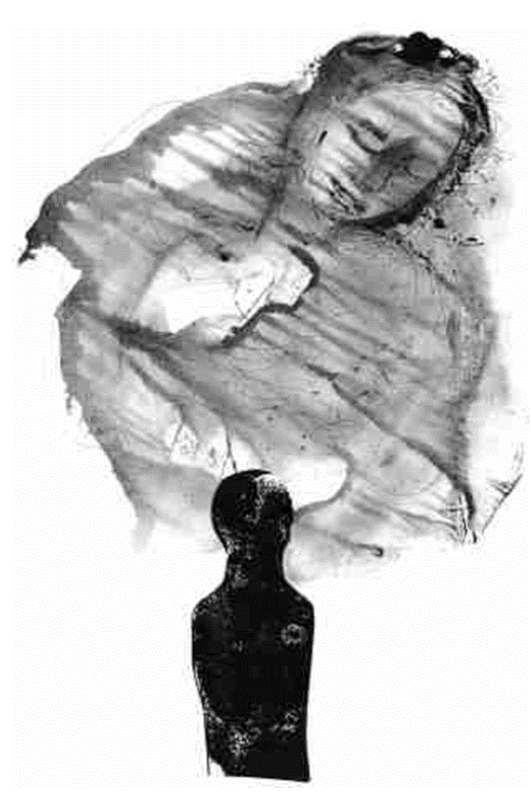

Török Levente illusztrációja

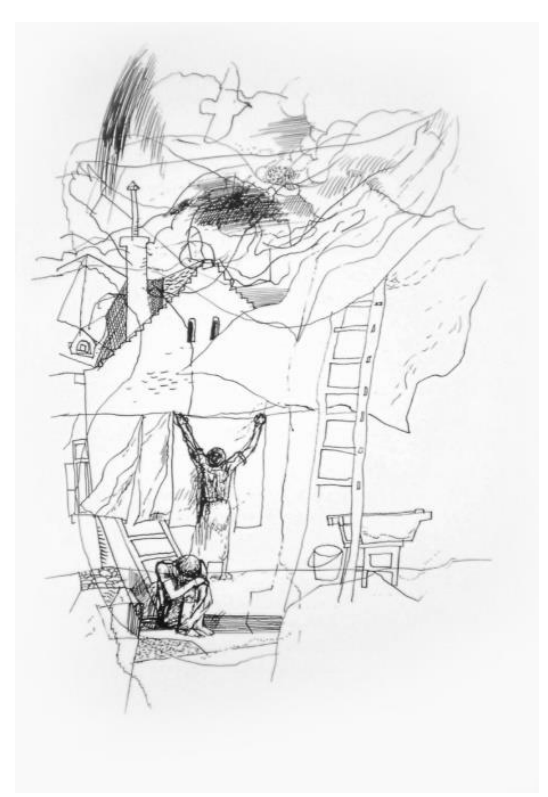

Würtz Ádám illusztrációja 
A szöveg hangzó formája véleményem szerint a vizuális megjelenítésnél is erösebben befolyásolja a referenciális jelentést. Ez azért is lehet így, mert a képi médium - nem lévén interszubjektíve értelmezhető notációrendszere - kevésbé egységes jelentést fejez ki, mint a prozódia, amelynek - az egyéni nyelvhasználói adottságok, szokások mellett is - grammatikai és stilisztikai szabályai is ismertek. Például a vers Latinovits Zoltán előadásában, Alan Anthony Silvestri Forrest Gump szvitjének zenei aláfestésével az értelmezői attitüdöt határozott mederben tartja. ${ }^{10}$ A szöveg multimediális kommunikátummá tágult komplexitása az értelmezői háttértudás tartományából előhívott ismeretek síkján is komplexebb mintázatot eredményez. Az a befogadó, aki ismeri a filmet, amelynek fő́ímzenéje az említett darab, szándékosan vagy ösztönösen párhuzamba állíthatja a film föszereplőjének édesanyjához való viszonyát azokkal a véleményekkel, amelyeket József Attilának az édesanyjához füződő viszonyával kapcsolatban ismerünk.

A szöveg értelmezésekor aktivált háttértudás vizsgálata és beépítése a szöveg referenciális jelentésének reprezentációjába rendkívül aprólékos és szerteágazó nézőpont alkalmazását kívánja meg, amelyek révén a szövegjelentésnek és a befogadói müködésnek apró részleteire derülhet fény.

\subsubsection{A kommunikatív jelentéssík}

Ahogyan fentebb, a jelentéssíkok rendszerének ismertetésekor erről szó volt, a kommunikatív jelentéssík egyenlő annak informativitásával, hogy az elemzett vers nyelvi elemeinek összes lehetséges sorrendi variációja közül melyik elrendezés (illetve melyik prozódiai struktúra) választódik ki egy-egy szöveghelyen. Tekintve, hogy a magyar nyelv szórendi szabályai és lehetőségei például három fogalmi jelentésű szónak 1x2×3, azaz hatféle helyes (jelentéses) szórendi variációját teszik lehetővé, a József Attila-vers esetében milliós nagyságrendủ az összes lineárisváltozat-mennyiség. Ez természetesen pusztán elvi megközelítés annak érzékeltetésére, hogy az aktuális kommunikációs helyzet és szövegkörnyezet hatása nyilvánul meg egy adott szöveg(részlet) kommunikatív jelentéssíkjának reprezentációjában.

Az alábbiakban a Mama című vers következő két sorának vizsgálatával szemléltetem a kommunikatív jelentéssík reprezentációjának szemiotikai textológiai módszerét.

Hagyja a dagadt ruhát másra.

Engem vigyen föl a padlásra.

Az első sor három fogalmi jelentésü kifejezése - mivel a dagadt ruhát a magyar nyelv grammatikájának megfelelően (változatlan szóalakok alkalmazásával) csak ebben az elrendezésben valósulhat meg - összesen hatféle szórendi változatban jelenhetne meg:

Hagyja a dagadt ruhát másra.

Hagyja másra a dagadt ruhát.

A dagadt ruhát hagyja másra.

A dagadt ruhát másra hagyja.

Másra a dagadt ruhát hagyja.

Másra hagyja a dagadt ruhát.

10 Az előadás elérhetősége: https://www.youtube.com/watch?v=4j-r2CS7oTU (2020.10.31.) 
A második sor esetében - mivel a magyar nyelv szintaxisában az igekötőnek „önálló élete” van, azaz gyakorlatilag bárhol megjelenhet a mondatban - a négy jelentéses kifejezés 24 szórendi variációt hozhat létre $(1 \times 2 \times 3 \times 4)$ :

Engem vigyen föl a padlásra.

Engem vigyen a padlásra föl.

Engem a padlásra vigyen föl.

Engem a padlásra fölvigyen.

Engem fölvigyen a padlásra.

Engem föl a padlásra vigyen.

Vigyen ...

Föl ...

A padlásra ...

A kommunikatív jelentéssík reprezentációjának fontos mozzanata annak magyarázata, hogy az összes lineáris elrendezési lehetőség közül vajon miért épp a fentebb kiemelt lineáris elrendezést alkalmazza a költő a versében.

A két sor másra és padlásra elemeinek mondatbeli helyzetét minden bizonnyal esztétikai törekvés (is) motiválhatja, páros rímet alkotnak.

A versen végigvonuló 'ő' és 'én' kontrasztját élesen fejezi ki a párhuzamos szerkesztés. Ezáltal voltaképpen rögzül az elemzett két mondat strukturális kerete.

[Ő] hagyja a dagadt ruhát másra.

Engem vigyen föl a padlásra.

A generatív grammatika diskurzuspozíciós modelljét véve alapul: az első egység kitöltetlen fókuszpozíciója miatt a fókuszhangsúly az igére esik; a második egységben az engem összetevő áll a fókuszban, kizárólagosan azonosított jelentéssel. Bár a másra nem szabályos fókuszpozícióban áll, erős hangsúlyt kap a másra - engem oppozíció miatt.

\subsubsection{Az asszociatív jelentéssík}

Az asszociatív jelentéssík vizsgálata az elemzett szöveg kapcsán izgalmas lehetőségeket vet fel.

A szöveg értelmezőjének élményvilága az a fö forrás, amelyből az egyéni asszociációk táplálkoznak. Ezt a forrást egyfelől meghatározzák a szociokulturális hatások, beleértve az adott korszakra érvényes jellegzetességeket az anya és fiúgyermek kapcsolatára vonatkozóan, másfelöl pedig az egyén személyes élményei, önreflexiói, érzései stb. Ezeknek a háttértudáselemeknek az aktiválása révén rendelhet hozzá az értelmező a szöveghez esztétikai értéket, bölcseleti tartalmat, értékítéletet vagy más természetü többletjelentést.

Ebből kiindulva az elemzett vers asszociatív jelentéssíkjának reprezentációja kapcsán a következő élményelemeket sorolhatjuk fel:

- az anya és a fiúgyermek kapcsolatáról való egyéni elképzelés (vs. általános hiedelmek);

- saját élmények, emlékek, benyomások, tapasztalati tudás az anya és a gyermek kapcsolatáról;

- az 'én mint gyermek' élményvilága;

- az 'én mint szülö’ élményvilága. 
Dobi Edit:

A szemiotikai textológiai jelentésreprezentáció hozadéka József Attila Mama cimü versének elemzésében

Argumentum 16 (2020), 260-279

Debreceni Egyetemi Kiadó

DOI: 10.34103/ARGUMENTUM/2020/16

\section{$5 \quad$ Összegzés és kitekintés}

A szemiotikai textológiai jelentésreprezentáció a szöveg jelentésének a vizsgálatát sajátos kognitív-pragmatikai keretbe utalja, ami azt eredményezi, hogy a befogadó nézőpontja - ide értve az összes olyan tényezőt, amely az értelmezés pillanatában a befogadó kognitív adottságait és képességeit meghatározza - erőteljesen előtérbe kerül. Ezen a szemléleten alapszik a szemiotikai textológiai részrendszerek felépítése, egymással való összehangoltságuk, ami olyan tipológiák kidolgozására ad lehetőséget, mint a kommunikátumok (köztük a dominánsan verbális szövegek) tipológiája, a tudásbázisok tipológiája, az interpretációtípusok rendszere.

Ezeknek az önmagukban igen összetett kereteknek a bemutatása túlmutat e dolgozat szorosan értelmezett törekvésén. A témakör továbbgondolása szempontjából lényeges jelenségként - rövid kitekintésként - a propozicionális attitüd fogalmát járom körül, mivel ez a befogadót jellemző olyan sajátosság, amely mérvadó egy szöveg jelentésének reprezentációjában.

A jelentésreprezentáció két fö forrása - ahogy ez az ismertetett esettanulmány kapcsán is látható - egyrészt a befogadó kognitív müveletei során felhasznált egyéni és kollektív tudás, másrészt a tudáselemek között a befogadó által felismert, rekonstruált, feltételezett stb. logikai, illetve asszociatív kapcsolatok halmaza. A befogadónak ezekre a logikai kapcsolatokra vonatkozó ítéleteiböl, következtetéseiből táplálkozik a befogadó propozicionális attitüdje, vagyis az a kognitív viszonyulás, amely meghatározza a befogadónak a szöveg értelméről teremtett egyéni világát.

Petőfi S. János a propozicionális attitűd fogalmát összeköti a lehetséges világokat alkotó kifejezésekkel, amelyekben a közlőnek az a magatartása jut kifejezésre, amellyel a saját kijelentéseit a való(s) világtól (mint referenciális bázistól) elhatárolja, és egyéni lehetséges világot teremt. A világalkotó tényezők közé olyan kifejezések tartoznak, mint tud, sejt, gyanit, hisz, feltételez, közöl stb. (1. Petőfi S. 1994). A világalkotó attitüdök a jelentés értelmezését filozófiai kérdéssé tágítják. David Lewis az analitikus filozófia keretében a lehetséges világok magyarázatával igazolja az értelmezői attitüd szerepét a jelentésleképezésben ${ }^{11}$ (Lewis 2004). Bár a lewisi filozófia nem emeli be gondolatkörébe az egyéni befogadói mentális leképezés teremtette világ jelenségét, elmélete zökkenőmentesen adaptálható a szemiotikai szövegfelfogás kutatásában. ${ }^{12}$

Petőfi S. János a szemiotikai textológiai jelentésleképezés magyarázatában a lehetséges világok elméletét - Csúri irodalomközpontú szövegszemléletéhez mérten - jóval általánosabb értelemben használja:

- A való világ szemiotikai textológiai értelemben - a fogalom által keltett asszociáció ellenére - nem egy nyelvtől függetlenül létező objektív valóság, hanem meghatározott konvenciók által valóságosként feltételezett világ.

- A szövegvilág a szövegvehikulum által feltehetően kifejezett tényállás-komplexum.

- A lehetséges világ a való világhoz való viszonyában értelmezhető, leegyszerüsítve feltételezett valóság. A közlő megnyilatkozásainak a propozicionális attitüd által szervezett összessé-

11 Vö. Bács \& Kocsis 2011.

12 Hatása több gondolkodó nézeteiben fellelhető: például Bernáth Árpád és Csúri Károly irodalmi szövegekre kidolgozott, a lehetséges világokat rendszerező konstruktivista modelljében (Bernáth \& Csúri 1981; Bernáth 1997), amely hatott a szemiotikai textológia keretében értelmezett világmodellekre is. A szemiotikai textológiába Petőfi S. által Csúri lehetséges világai nyomán beemelt világfogalmak révén megragadhatóvá válnak az interpretációban lényeges tudásbázisok (Petőfi S. 1994). 
ge, amelyben a szövegvilág tényállásai az értelmező számára igaznak, lehetségesnek minősülnek.

- A részvilág a világfragmentum valamely összetevője, amelyet valamilyen szempontból el tudunk különíteni a világ többi összetevőjétől.

A világok rendszere a befogadó konstringenciaítéletével úgy függ össze, hogy ha a befogadói ítélet, ill. benyomás egy adott tényállás-konfigurációt el tud fogadni mint egy lehetséges világhoz tartozó konfigurációt, akkor az adott tényállás-konfigurációt konstringensnek minősíti.

\section{Irodalom}

Bács G., Kocsis L. (2011): Lewis a világok sokaságáról. Magyar Filozófiai Szemle 2011/4, 153-177.

de Beaugrande, R.-A. \& Dressler, W. U. (1981): Einführung in die Textlinguistik. Tübingen: Max Niemeyer Verlag. https://doi.org/10.1515/9783111349305

Bernáth Á. (1997): A lehetséges világok poétikai elméletének szellemi gyökerei. Helikon Irodalomtudományi Szemle 43, 377-393.

Bernáth Á. \& Csúri K. (1981): A „lehetséges világok” szemantikájának relevanciája. Magyar Mühely 19 (64), 19-33.

Bókay A. (1979): A szövegelmélet modelljei és alkalmazási lehetőségük. In: Szathmári I., Várkonyi I. (szerk.): A szövegtan a kutatásban és az oktatásban. Budapest: Magyar Nyelvtudományi Társaság, 47-55.

Csúri K. (1987): Lehetséges világok. Tanulmányok az irodalmi müértelmezés témaköréböl. Budapest: Tankönyvkiadó.

Daneš, F. (1970/1982): A szövegstruktúra nyelvészeti elemzéséhez. In: Thomka B. (szerk.): Tanulmányok 15. Szövegelmélet. Újvidék: A Magyar Nyelv, Irodalom és Hungarológiai Kutatások Intézete, 45-50.

Daneš, F. \& Viehweger, D. (Hg.) (1976): Probleme der Textgrammatik I. (Studia grammatica XI.) Berlin: Akademie-Verlag.

Daneš, F. \& Viehweger, D. (Hg.) (1977): Probleme der Textgrammatik II. (Studia grammatica XVIII.) Berlin: Akademie-Verlag.

van Dijk, T. A. (1972): Some Problems of Text Grammars. The Hague: Mouton. https://doi.org/10.1515/9783110804263

van Dijk, T. A. (1977/1982): Kontextus és megismerés. Tudáskeretek és beszédaktus-megértés. In: Thomka B. (szerk.): Tanulmányok 15. Szövegelmélet. Újvidék: A Magyar Nyelv, Irodalom és Hungarológiai Kutatások Intézete, 63-81.

van Dijk, T. A. (1977): Text and Context. Explorations in the Semantics and Pragmatics of Discourse. London: Longman.

van Dijk, T. A. (1980): Textwissenschaft. Tübingen: Niemeyer. https://doi.org/10.1515/9783110954845

Dobi E. (szerk.) (2011): A szövegösszefüggés elméleti és gyakorlati megközelítési módjai. Poliglott terminológiai és fogalmi áttekintés. Petőfi S. János 80. születésnapjára. Officina Textologica 16.

Dobi E. (2011): A szemiotikai textológia a magyar szövegtani kontextusban. Terminológiai kérdések a magyar nyelv szövegtanában. Officina Textologica 16, 11-36. 
Dobi E. (2012): A szemiotikai textológiai jelértelmezés szerepe a szöveg jelentésreprezentációjában. Magyar Nyelvjárások 50, 107-116.

Dobi E. (2013): A nem tipikus szövegek jelentésreprezentációjának egy kérdéséről. Magyar Nyelvjárások 51, 169-177.

Dobi E. (2015): Konstringencia és tematikus progresszió. Magyar Nyelvjárások 53, 121-128.

Dobi E. (2016): Gondolatok a koherenciáról. Officina Textologica 19, 11-20.

Dobi E. (2019): A konstringencia lexiko-szemantikai vonatkozása. Argumentum 15, 534-544.

Halliday, M. A. K. (1968): The Users and Uses of Language. In: J. A. Fishman (ed.): Readings in the Sociology of Language. The Hague: Mouton, 139-169. https://doi.org/10.1515/9783110805376.139

Halliday, M. A. K. (1985): An Introduction to Functional Grammar. London: Edward Arnold.

Halliday, M. A. K. \& Hasan, Ruqaiya (1976): Cohesion in English. London: Longman.

Hartung, W. (1983): Sprache und Kommunikation. In: W. Fleischer et al. (Hg.): Deutsche Sprache. Kleine Enzyklopädie. Leipzig: Bibliographisches Institut, 345-381.

Kallmeyer W., Klein, W., Meyer-Hermann, R., Netzer, K. \& Siebert, H.-J. (1974): Lektürekolleg zur Textlinguistik 1-2. Frankfurt: Athenäum.

Lewis, D. (2004): Lehetséges Világok. In: Farkas K., Huoranszki F. (szerk.): Modern Metafizikai Tanulmányok. Budapest: Eötvös Kiadó, 91-99.

Petőfi S. J. (1994): Lehetséges világok - szövegvilágok. In: Petőfi S. J., Bácsi J., Békési I., Benkes Zs. \& Vass L.: Szövegtan és prózaelemzés. A rövidpróza kreativ-produktív megközelitéséhez. Budapest: Trezor Kiadó, 41-61.

Petőfi S. J. (2004): A szöveg mint komplex jel. Bevezetés a szemiotikai textológiai szövegszemléletbe. Budapest: Akadémiai Kiadó.

Petöfi S. J. (2008): A szemiotikai textológia elnevezésü szövegtani diszciplína megokoltságáról, jellemzö jegyeiröl és alkalmazásáról. (Szemléltető példa: egy multimediális szöveg szemiotikai-textológiai megközelítése.) Előadásként elhangzott 2008. április 7-én.

\author{
Dobi Edit \\ Debreceni Egyetem \\ Magyar Nyelvtudományi Tanszék \\ H-4002 Debrecen \\ Pf. 400 \\ dobi.edit@arts.unideb.hu
}

